| Fenomena Lapak Mesum

\title{
FENOMENA LAPAK MESUM Di KAWASAN WISATA GRONGGONG KABUPATEN CIREBON SEBAGAI TEMPAT PERGAULAN BEBAS Di KALANGAN REMAJA.
}

\author{
Yeni Wahyuni ${ }^{1}$
}

\begin{abstract}
s
Behavior promiscuity now this can be done by anyone, anytime and anywhere, including the one in the area of tourism. In tourist areas often appeared behavioral Gronggong promiscuity among teenagers. This study aims to: 1). Describe the factors that cause a nasty stall in the area of tourism can be a region Gronggong promiscuity among teenagers, 2). The effort to control local government officials in tourism mentertibkan Gronggong of behavior promiscuity among teenagers.

This study uses qualitative research methods with the primary data source consists of the visitors, the traders in the Area Tourism Gronggong, PP Satpol Cirebon District, the Village Head Patapan Cirebon, Cirebon District Head of Tourism, and Communities around Gronggong tourist area, while for source secondary data obtained through documentation, literature study using books, and print media. Data collection techniques used include observation, interviews, and documentation. The subjects in this study were the visitors and the traders in the tourist areas Gronggong with 4 stall traders. The technical validity of the data in this study using the technique of triangulation of sources and methods. In the data analysis techniques using the interactive analysis of Miles and Huberman.

The results obtained are the factors that cause a nasty stall in the area of tourism can be a region Gronggong promiscuity among teenagers consists of: 1). Nonphysical factors consist of building construction shanties. Shanties located on the left path has an insulated building, located there under (the category is not visible), stall located on the right road in the form of benches scattered, and many benches that are built on a hill standing upright. The lack of lighting (illumination). While physical factors consist of a dynamic social relations between traders and visitors Gronggong tourist area, and factors of social control of local government officials are less than optimal. 2). The effort to control local government officials in tourism mentertibkan Gronggong of promiscuity behaviors among adolescents such as by recording the location then the insulated, provide guidance, socialization, and in its supervision on patrol every single week, right the situation is done at a certain time and depending on the needs, as before the religious holidays, and towards the end of the year.
\end{abstract}

Keywords: Phenomenon bawdy shanties, adolescents, and control.

\footnotetext{
${ }^{1}$ Alumni Pendidikan Sosiologi FIS UNY
} 


\section{A. Pendahuluan}

Pada zaman sekarang ini, masalah remaja sudah menjadi suatu masalah yang cukup pelik. Hal ini dikarenakan dampaknya yang cukup besar bagi perkembangan lingkungan masyarakat. Masalah seks pada remaja seringkali mencemaskan para orang tua, pendidik, pejabat pemerintahan, para ahli dan sebagainya. Remaja adalah periode peralihan ke masa dewasa, di mana mereka seyogyanya mulai mempersiapkan diri menuju kehidupan dewasa, termasuk dalam aspek seksualnya (Sarlito Wirawan Sarwono, 2006:174). Masa remaja merupakan masa transisi, di mana mereka sangat mudah untuk dipengaruhi. Statusnya yang transisi itu sendiri sudah merupakan masalah pada remaja, sehingga dapatlah dikatakan bahwa wajar jika remaja itu bermasalah. Walaupun demikian, berbagai usaha tetap dilakukan untuk mengetahui faktor khusus apa yang berpengaruh dalam masa transisi ini sehingga para remaja itu mengakui berbagai masalah tentang seks. Salah satu anggapan yang sering dikemukakan orang adalah kurangnya keyakinan seseorang dalam beragama. Dikatakan pula bahwa perilaku seksual yang dilakukan oleh para remaja bertentangan dengan norma agama yang disebabkan oleh merosotnya kepercayaan pada agama. Sehingga, perilaku seksual yang dilakukan oleh remaja dapat dicegah dengan meningkatkan keyakinan dalam beragama (Sarlito Wirawan Sarwono, 2006:179). Kebebasan seks di kalangan remaja sebagai fenomena dipandang cukup meresahkan. Hal tersebut ditandai dengan adanya hubungan pacaran di kalangan remaja sampai dengan pergaulan bebas atau sex bebas di kalangan remaja. Hubungan seksual yang biasanya dilakukan secara sah oleh suatu pasangan dan dilakukan dalam ruang privat, sekarang mulai dilakukan secara bebas dan bahkan telah keluar dari batas-batas privasi seseorang serta dapat menjadi konsumsi publik. Para remaja itu beranggapan bahwa seks adalah sesuatu yang bebas dilakukan oleh siapa saja dan di mana saja.

Kawasan Wisata Gronggong terletak di jalur kuning Kabupaten Cirebon. Dahulu tempat wisata ini begitu indah, namun beberapa waktu kemudian banyak dipenuhi lapak para pedagang dan lapak pengunjung, sehingga tempat wisata ini terlihat kumuh. Pemerintah Kabupaten Cirebon menetapkan Gronggong sebagai kawasan wisata, namun citra Gronggong selalu negatif karena adanya gubuk-gubuk bersekat yang kerap menjadi tempat mesum pasangan muda-mudi. Lapak-lapak pengunjung berupa gubuk bersekat, gubuk yang berada di bawah (kategori tidak terlihat), bangku yang berpencar, dan bangku berdiri tegak di atas bukit yang terdapat di kawasan wisata Gronggong Kabupaten Cirebon, kerap menjadi tempat pergaulan bebas di kalangan remaja. 
Fenomena Lapak Mesum

B. Rumusan Masalah

Adapun masalah yang dapat dirumuskan dalam penelitian ini adalah

1. Faktor-faktor apa yang menyebabkan fenomena lapak mesum di kawasan wisata Gronggong Kabupaten Cirebon bisa menjadi kawasan pergaulan bebas di kalangan remaja?

2. Bagaimana upaya penanggulangan aparat pemerintah setempat dalam mentertibkan kawasan wisata Gronggong dari perilaku pergaulan bebas di kalangan remaja tersebut?

\section{Kajian Pustaka}

Fenomena yang terjadi pada akhir-akhir ini adalah banyak adanya pergaulan bebas di kalangan remaja yang melakukan perbuatan melanggar nilai dan norma yang ada di masyarakat dan hal-hal yang dilarang oleh agama seperti laki-laki dan perempuan yang bukan muhrim duduk berduaan di tempat yang sepi, apalagi saling bercumbu rayu, berpelukan, tingkah laku berkencan, dan bersenggama. Remaja adalah usia transisi. Seorang individu, telah meninggalkan usia kanak-kanak yang lemah dan penuh kebergantungan, akan tetapi belum mampu ke usia yang kuat dan penuh tanggung jawab, baik terhadap dirinya maupun terhadap masyarakat. Banyaknya masa transisi ini bergantung kepada keadaan dan tingkat sosial masyarakat di mana ia hidup.
Semakin maju masyarakat semakin panjang usia remaja, karena ia harus mempersiapkan diri untuk menyesuaikan diri dalam masyarakat yang banyak syarat dan tuntutannya (Sofyan S. Willis, 2005:24). Perilaku seksual adalah segala tingkah laku yang didorong oleh hasrat seksual, baik dengan lawan jenisnya maupun dengan sesama jenis. Bentuk-bentuk tingkah laku ini bisa bermacam-macam, mulai dari perasaan tertarik sampai tingkah laku berkencan, bercumbu, dan bersenggama.

Interaksi sosial merupakan hubungan-hubungan sosial yang dinamis yang menyangkut hubungan anata orang perorangan, antara kelompok-kelompok manusia, maupun antara orang perorangan dengan kelompok manusia (Soerjono Soekanto, 2005:61). Syarat terjadinya interaksi sosial terdiri dari kontak dan komunikasi sosial. Interaksi sosial antara pedagang dan pengunjung di kawasan wisata Gronggong berjalan dengan baik. Terjadi kontak sosial dan dilanjutkan dengan komunikasi pada saat pedagang menawarkan dagannya kepada para pengunjung, ketika pengunjung memesan makanan dan minuman sampai dengan pengunjung meninggalkan kawasan wisata Gronggong tersebut.

\section{Kajian Teori}

Berdasarkan teori tentang fenomenologi, merupakan studi tentang fenomena hal-hal yang kita sadari muncul kepada kita, dan cara 
yang paling mendasar dari pemunculannya adalah sebagai suatu aliran pengalamanpengalaman inderawi yang berkesinambungan yang kita terima melalui panca indera kita. Pandangan Alfred Schutz terhadap teori ini memusatkan perhatiannya bagaimana orang memahami kesadaran orang lain sementara mereka hidup dalam arus kesadaran mereka sendiri (Craib Ian, 1992:128129). Teori fenomenologi juga menyebutkan bahwa fenomenologi yang merupakan sebuah teori yang memiliki pemaknaan terhadap sesuatu berdasarkan sudut pandang orang pertama.

Dalam

pandangan

interaksionisme simbolik manusia bukan dilihat sebagai produk yang ditentukan oleh stuktur atau situasi obyektif, tetapi paling tidak sebagian merupakan aktor-aktor yang bebas. Interaksionisme simbolik dilakukan dengan menggunakan bahasa, sebagai satusatunya simbol yang terpenting dan melalui isyarat. Pada intinya, teori ini menyatakan bahwa tanggapan seseorang tidak dibuat secara langsung terhadap tindakan lain, tetapi didasarkan pada "makna" yang diberikan terhadap tindakan orang lain tersebut. Interaksi antar individu dijembatani oleh penggunaan simbol-simbol, interpretasi atau saling berusaha untuk saling memahami maksud dari tindakan masing-masing individu. Berdasarkan teori interaksionisme simbolik juga menyatakan bahwa dalam proses interaksi sosial, manusia secara simbolik mengkomunikasikan arti terhadap orang lain yang terlibat, kemudian orang lain menafsirkan simbol komunikasi itu dan mengorientasikan tindakan balasan mereka berdasarkan penafsiran mereka. Dengan kata lain, dalam interaksi sosial para aktor terlibat dalam proses saling mempengaruhi. Artinya ada hubungan timbal balik antara keduanya (George Ritzer, 2004:293). Individu sebagai aktor memiliki kesadaran mengenai apa yang dilakukannya berdasarkan obyek yang diketahui dan diamatinya. Blumer menyebut kondisi ini sebagai proses selfindication. Proses self-indication merupakan proses komunikasi yang sedang berjalan yaitu individu mengetahui sesuatu, menilainya, memberinya makna, dan memutuskan untuk bertindak berdasarkan makna itu (Magaret M. Poloma, 2007:258).

Perilaku

menyimpang dianggap menjadi sumber masalah sosial karena dapat membahayakan tegaknya sistem sosial. Perilaku menyimpang juga merupakan perilaku dari para warga masyarakat yang dianggap tidak sesuai dengan kebiasaan, tata aturan atau norma sosial yang berlaku.

Perilaku menyimpang secara umum dapat digolongkan sebagai berikut:

1. Tindakan yang nonnconfrom, yaitu perilaku yang tidak sesuai dengan nilai-nilai atau norma-norma yang ada.

2. Tindakan yang antisosial atau asosial yaitu tindakan yang melawan kebiasaan masyarakat atau kepentingan umum. 
Fenomena Lapak Mesum

3. Tindakan-tindakan kriminal, yaitu tindakan yang nyatanyata telah melanggar aturanaturan hukum tertulis dan mengancam jiwa atau keselamatan orang lain (J. Dwi Narwoko, 2010:101).

Perilaku menyimpang dapat didefinisikan secara berbeda berdasarkan empat sudut pandang antara lain:

1. Secara statistikal, segala perilaku yang bertolak dari suatu tindakan yang bukan rata-rata atau perilaku yang jarang dan tidak sering dilakukan.

2. Secara absolute atau mutlak, definisi perilaku menyimpang yang berasal dari kaum absolutis ini berangkat dari aturan-aturan sosial yang dianggap sebagai sesuatu yang mutlak atau jelas dan nyata, sudah ada sejak dulu, serta berlaku tanpa terkecuali untuk semua warga masyarakat.

3. Secara reaktif, perilaku menyimpang menurut kaum reaktivitas bila berkenaan dengan reaksi masyarakat atau agen kontrol sosial terhadap tindakan yang dilakukan seseorang. Artinya, apabila ada reaksi dari masyarakat atau agen kontrol sosial dan kemudian mereka memberi cap atau tanda (labeling terhadap si pelaku, maka perilaku itu telah dicap menyimpang).

4. Secara normatif, penyimpangan adalah suatu pelanggaran dari suatu norma sosial (J. Dwi Narwoko, 2010:105).

Rangkaian pengalaman menyimpang seseorang dimulai dari penyimpangan kecil yang mungkin tidak disadarinya. Jenis penyimpangan semacam itu disebut dengan penyimpangan primer. Penyimpangan jenis ini dialami oleh seseorang dimana ia belum memiliki konsep sebagai penyimpang atau tidak menyadari jika perilakunya menyimpang. Bentuk penyimpangan primer ini biasanya dialami oleh seseorang yang tidak menyadari bahwa perilakunya dapat menjurus kearah penyimpangan yang lebih berat. Penyimpangan yang lebih berat akan terjadi apabila seseorang sudah sampai pada tahap penyimpangan sekunder, yaitu suatu tindakan menyimpang yang berkembang ketika perilaku dari penyimpangan itu mendapat penguatan melalui keterlibatannya dengan orang atau kelompok yang juga menyimpang. Bentuk penyimpangan sekunder berasal dari hasil penguatan penyimpangan primer. Tindakan menyimpang, baik primer maupun sekunder tidak terjadi begitu saja tapi berkembang melalui suatu periode waktu dan juga sebagai hasil dari serangkaian tahapan interaksi yang melibatkan interpretasi tentang kesempatan untuk bertindak menyimpang. Karier menyimpang juga didukung oleh pengendalian diri yang lemah serta kontrol masyarakat yang 
longgar (J. Dwi Narwoko, 2010:106107).

\section{E. Metode Penelitian}

Penelitian ini mengambil setting di kawasan wisata Gronggong Desa Patapan Kecamatan Beber Kabupaten Cirebon Jawa Barat. Dalam penelitian ini peneliti melakukan penelitian yang berpindah-pindah dari satu lapak pedagang ke lapak pedagang lainnya sampai mendapatkan data atau informasi yang valid. Sumber data primer dalam penelitian ini adalah pengunjung wisata Gronggong, para pedagang di kawasan wisata Gronggong, satpol PP Kabupaten Cirebon, kepala Desa Patapan Kabupaten Cirebon, kepala bidang pariwisata Kabupaten Cirebon, dan masyarakat sekitar kawasan wisata Gronggong. Sumber data sekunder ini diperoleh melalui dokumentasi dan studi kepustakaan melalui buku-buku, media cetak. Jenis data dalam penelitian ini adalah data kualitatif di mana data-data yang dikumpulkan berupa kata-kata, gambar dan bukan angka. Data yang disajikan berupa tulisan deskriptif analisis hasil dari wawancara dan sumber lainnya dengan hasilnya adalah ketikan dari komputer dan jenisnya berupa laporan.

Teknik pengumpulan data bertujuan untuk memperoleh data dengan cara-cara yang sesuai dengan penelitian sehingga peneliti akan memperoleh data yang lengkap. teknik pengumpulan data yang digunakan observasi, wawancara, dan dokumentasi.
Subyek penelitian adalah seseorang atau sesuatu benda yang mengenainya ingin diperoleh maksud tertentu akibat dari apa yang ditimbulkan (Tatang M. Amirin, dalam Vina Emiyati, 2006:30). Dikarenakan subyek penelitian adalah seseorang maka obyek yang diteliti adalah perilaku atau perbuatan dari yang bersangkutan. Dalam penelitian ini, subyek penelitian adalah para pengunjung dan para pedagang di kawasan wisata Gronggong dengan jumlah empat lapak para pedagang yang merupakan para informan yang kompeten atau yang dianggap mengetahui pokok permasalahan yang dikaji. Teknik triangulasi yang digunakan dalam penelitian ini adalah triangulasi sumber, dan triangulasi metode. Triangulasi sumber yakni dilakukan dengan pengecekkan derajat kepercayaan beberapa sumber data dengan mengumpulkan data yang sejenis dengan metode yang sama yaitu wawancara mengecek derajat kepercayaan sumber pada informan yang berbeda-beda. triangulasi metode yakni mengumpulkan data yang sejenis dengan menggunakan teknik pengumpulan data yang berbeda yaitu mengumpulkan data dari hasil wawancara, dan observasi dan analisa dokumen. Teknik analisis yang digunakan adalah analisis interaktif Miles dan Huberman. Analisis ini menggunakan empat komponen analisis yaitu pengumpulan data, reduksi data, sajian data, dan kesimpulan (Miles dan Huberman, 1992:20). Aktivitas ini dilakukan 
Fenomena Lapak Mesum

berulang-ulang hingga membentuk sebuah siklus.

\section{F. Pembahasan}

Akhir-akhir ini fenomena pergaulan bebas antara pria dan wanita semakin marak terjadi. Mereka ingin bebas bergaul dengan siapa saja, baik laki-laki maupun wanita di seluruh dunia tanpa batas. Agama yang kolot, frustasi dan kehidupan yang terbelenggu yang mengekang kebebasan kaum wanita. Ditinjau dari ilmu psikologi pendidikan dari sudut pandang Islam, pergaulan bebas antara pria dan wanita tanpa batas dan tidak dilandasi oleh kaidah-kaidah dan norma-norma susila, sangat membahayakan generasi muda, terutama kepada generasi mudamudi atau remaja. Alasannya telah cukup dikemukakan, agama tidak membenarkan. Agama melarang laki-laki dan perempuan yang bukan muhrim duduk di tempat sepi berduaan, apalagi saling bercumbu rayu, berpelukan dan berkhalawat berada di tempat yang bersembunyi berdua-duaan karena nantinya akan hadir orang ketiga yaitu setan (Yatimin, 2003:58). Masa remaja merupakan masa transisi dari masa kanak-kanak ke masa dewasa. Pergaulan remaja sekarang ini sangat membutuhkan perhatian yang sangat ekstra tertutama dari pihak keluarga. Pergaulan bebas merupakan fenomena umum yang sekarang semakin marak terjadi. Perilaku pergaulan bebas sekarang ini dapat dilakukan di mana pun, kapan pun dan dapat dilakukan oleh siapapun bahkan bukan dengan pasangan sahnya sehingga menjadi konsumsi publik.

Berdasarkan teori tentang fenomenologi, merupakan studi tentang fenomena hal-hal yang kita sadari muncul kepada kita, dan cara yang paling mendasar dari pemunculannya adalah sebagai suatu aliran pengalamanpengalaman inderawi yang berkesinambungan yang kita terima melalui panca indera kita. Pandangan Alfred Schutz terhadap teori ini memusatkan perhatiannya bagaimana orang memahami kesadaran orang lain sementara mereka hidup dalam arus kesadaran mereka sendiri (Craib Ian, 1992:128129). Dalam teori fenomenologi juga menyebutkan bahwa fenomenologi yang merupakan sebuah teori yang memiliki pemaknaan terhadap sesuatu berdasarkan sudut pandang orang pertama. Penelitian tentang fenomena lapak mesum di kawasan wisata Gronggong sebagai tempat pergaulan bebas di kalangan remaja ini merupakan fenomena sosial dan merupakan kejadian nyata yang dapat ditangkap dengan panca indera kita. Penelitian ini juga memaknai pengalaman-pengalaman para pedagang yang ada di kawasan wisata Gronggong yang memiliki makna tersendiri mengenai pekerjaannya berdasarkan pengalaman dari diri sendiri dan juga pengalaman pedagang lainnya. Banyak pengalaman para pedagang satu dengan pedagang lain di sana rasakan tentang perilaku pergaulan para pengunjungnya terutama 
remaja ketika berkunjung ke kawasan wisata Gronggong. Banyak pengunjung yang datang terutama para remaja memilih lapak berupa tempat duduk yang berbilik-bilik jika siang hari, memilih bangkubangku yang berpencar-pencar, dan memilih bangku yang berada di bawah (kategori tidak terlihat) jika malam hari dan itu sangat gelap sehingga orang pun tidak mengetahui apakah di situ ada orang atau tidak sehingga mereka memanfaatkan situasi dan kondisi tersebut untuk melakukan perbuatan yang tidak diinginkan atau berbuat mesum.

Berdasarkan teori interaksionisme simbolik juga menyatakan bahwa dalam proses interaksi sosial, manusia secara simbolik mengkomunikasikan arti terhadap orang lain yang terlibat, kemudian orang lain menafsirkan simbol komunikasi itu dan mengorientasikan tindakan balasan mereka berdasarkan penafsiran mereka. Dengan kata lain, dalam interaksi sosial para aktor terlibat dalam proses saling mempengaruhi. Artinya ada hubungan timbal balik antara keduanya (George Ritzer, 2004:293). Lapak pedagang di sana ada juga yang memberikan simbol berupa kata-kata bahwa "bangku di atas banyak". Hal itu memberitahukan dan mengkomunikasikan kepada para pengunjung, bahwa lapak pengunjung berupa bangku-bangku yang berada di atas (di atas bukit) itu masih banyak tersedia, sehingga para pengunjung memberikan timbal balik kepada para pedagang atau mengorientasikan tindakan mereka itu dengan memilih dan menempati bangku-bangku yang berada di atas tadi. Dalam proses interaksionisme simbolik juga menyebutkan adanya proses selfindication yang merupakan proses komunikasi yang sedang berjalan yaitu individu mengetahui sesuatu, menilainya, memberinya makna, dan memutuskan untuk bertindak berdasarkan makna itu. Berdasarkan hal tersebut, para pedagang di kawasan wisata Gronggong mengetahui tentang perilaku yang dilakukan oleh para pengunjung yang ada di sana, baik itu perilaku yang baik artinya pengunjungnya itu benar-benar menikmati pemandangan, duduk santai, dan menikmati makanan yang disajikan sampai dengan perilaku yang negatif artinya memanfaatkan situasi dan kondisi tersebut untuk melakukan hal-hal yang dilarang. Para pedagang memberikan penilaian atas perilaku pengunjungnya tersebut, dan memiliki makna tersendiri, agar dagangannya laris dan ramai dikunjungi oleh para pengunjung yang datang kesana yang rata-rata para remaja, pedagang bertindak berdasarkan makna dengan mengambil tindakan untuk membuat lapak yang tahu keinginan pengunjungnya itu seperti bangku-bangku yang bersekat-sekat, tertutup, berpencarpencar yang sebenarnya konstruksi bangunan lapaknya itu menyalahi aturan yang ada. Lapak yang menyalahi aturan tersebut dibongkar oleh aparat pemerintah setempat, yang kemudian setelah dibongkar dan dibangun kembali 
oleh para pedagang di sana. Kawasan wisata Gronggong harus dipergunakan sesuai dengan fungsinya agar tidak terjadi suatu keresahan dalam masyarakat. Kawasan wisata ini merupakan fungsi manifes yang artinya sesuatu dikehendaki (Ritzer George, 2004;272). Fungsi manifes kawasan wisata Gronggong ini digunakan untuk berwisata, refreshing, melepaskan penat yang ada, menikmati panorama indah Kota Cirebon dari puncak Gronggong sembari menyantap makanan yang tersedia dengan ciri khas makanannya berupa jagung bakar. Selain itu, dapat meningkatkan perekonomian warga masyarakat sekitar. Namun, kawasan wisata Gronggong memiliki fungsi laten yang artinya sesuatu tidak dikehendaki (Ritzer George, 2004;272) yaitu lapak pengunjung di kawasan wisata Gronggong kerap dimanfaatkan oleh pengunjung yang datang untuk melakukan perbuatan mesum atau perbuatan asusila yang berlawanan dengan nilai dan norma dalam masyarakat.

Obyek wisata Gronggong merupakan salah satu bagian dari obyek pariwisata unggulan Kabupaten Cirebon. Di antara sebelas objek wisata unggulan yang dimiliki Kabupaten Cirebon, peneliti memilih kawasan wisata Gronggong untuk menjadi tempat untuk melakukan penelitian karena dengan alasan bahwa kawasan wisata Gronggong yang merupakan bagian dari wisata kuliner karena di kawasan wisata tersebut banyak terdapat berbagai macam jenis makanan dan minuman mengapa sering dilakukan razia atau penertiban yang dilakukan oleh aparat pemerintah setempat (Satuan Polisi Pamong Praja). Hal tersebut tidak dapat terjadi dengan sendirinya, pasti ada faktor-faktor yang membuat razia atau penertiban itu terjadi. Luas lahan di Kawasan wisata Gronggong kurang lebih sekitar $100 \mathrm{Ha}$, dengan ruas jalan sebelah kiri dan kanan dipenuhi oleh lapak para pedagang yang identik berjualan jagung bakar. Terdapat pula lapak pengunjung yang merupakan tempat duduk untuk para pengunjung berupa bangkubangku, dan gubuk-gubuk kecil yang terbuat dari kayu dan bambu. Lapak-lapak pengunjung digunakan untuk menjadi tempat duduk para pengunjungnya ketika menikmati santapan yang disediakan para pedagang di sana, sembari menyaksikan seluruh perkampungan Kabupaten Cirebon dan kerlap-kerlip lampu di kota Cirebon dari atas Gronggong, dan juga tempat beristirahat para pengendara.

Para pedagang membangun sendiri lapak-lapak bagi para pengunjungnya berupa bangkubangku dan gubuk-gubuk kecil, untuk dijadikan tempat duduk para pengunjungnya. Pada akhirnya lapak-lapak yang dibangun sendiri oleh para pedagang yang ada di sana melanggar Peraturan Daerah (Perda) tentang K3 yaitu kebersihan, ketertiban, dan keindahan. Jumlah 
lapak pedagang di kawasan wisata Gronggong sekitar 80 lapak mayoritas berjualan jagung bakar dan minuman, tetapi ada 9 lapak pedagang yang sudah digusur, sisanya ada yang pedagang musiman kemudian ada yang masih berjualan dan ada yang sudah tidak berjualan lagi. Pedagang musiman berdagang jika pada malam perayaan pergantian tahun atau malam tahun baru saja karena pada malam tahun baru sangat ramai dikunjungi wisatawan dari berbagai daerah. Pada malam puncak perayaan pergantian tahun, kawasan wisata Gronggong bak seperti kawasan puncak Bogor Jawa Barat penuh dan sangat ramai dikunjungi oleh para pengunjung dan jalanannya pun macet di penuhi banyak kendaraan. Kurang lebih sekitar 24 lapak pedagang yang berada di seberang kanan ruas jalan tersebut di sponsori oleh PT Djarum di mana para pedagang tidak membayar retribusi apapun.

Dahulu kawasan wisata Gronggong ini begitu indah, namun beberapa waktu kemudian banyak dipenuhi lapak para pedagang dan lapak pengunjung sehingga tempat wisata ini terlihat kumuh hingga saat ini kondisinya masih kurang terawat. Lapak pengunjung yang berupa bangku-bangku terbuat dari kayu dan bambu masih terus dibiarkan berdiri di atas bukit sehingga membuat kondisi semakin tidak terawat dan tidak nyaman untuk dilihat oleh siapapun terutama para wisatawan. Keberadaan pedagang yang ada di sepanjang jalan kawasan wisata Gronggong belum tertata dengan baik sehingga mengganggu keindahan kota.

Padahal jika dilakukan penataan potensi alam kawasan wisata Gronggong tersebut sangat menjanjikan. Pemerintah Kabupaten Cirebon tidak memiliki kewenangan penuh untuk membeli atau menyewa lahan tersebut yang jika di uangkan kurang lebih sekitar 5 milyar karena lahan tersebut masih milik lahan pribadi orang. Pemerintah setempat tidak bisa melarang mereka untuk berdagang di sana, tetapi hanya bisa mengarahkan dan mengatur ketertiban untuk tertib sesuai dengan peraturan yang ada. Rencana ke depan aparat pemerintah setempat bisa membeli tanah itu kalau memungkinkan karena membutuhkan anggaran yang cukup besar jika untuk membeli lahan tersebut, tetapi tidak tahu kapan akan terealisasikannya, kalau sekarang mereka hanya memberikan masukan-masukan, saran kepada para pedagang, kalau untuk menata ulang keseluruhan mereka belum bisa karena kendalanya di lahan karena lahan tersebut masih lahan milik orang lain dan aparat pemerintah tidak punya kewenangan penuh untuk membeli atau menyewa karena lahan tersebut milik pribadi orang, di sini mereka hanya mengatur ketertiban. Rencananya pemerintah setempat ingin membuka kawasan wisata Gronggong ini lebih berkembang lagi seperti wisata air, wisata out bond, taman kota karena kawasan wisata Gronggong memiliki lahan yang cukup luas dan 
didukung dengan potensi alam yang sangat menjanjikan.

$$
\text { Faktor-Faktor Penyebab }
$$

Terjadinya Pergaulan Bebas di Kawasan Wisata Gronggong terdiri dari :

1. Faktor Fisik

a. Konstruksi Bangunan Lapak

1) Lapak pedagang dan lapak pengunjung berada di sebelah kiri jalan

Pemilik bangunan yang berada di sisi jalan sebelah kiri sungguh kreatif. Mereka membuat gubuk-gubuk kecil terbuat dari kayu dan bambu berkapasitas dua orang yang disekat-sekat, berbilikbilik layaknya seperti warnet (warung internet) yang diberi penerangan seadanya sehingga terlihat sangat gelap. Lapak pedagang sebelah kiri jalan jika siang hari memang sudah ramai banyak dikunjungi oleh para pengunjung mayoritas para kawula muda bahkan para pelajar yang masih menggunakan seragam dari pagi sampai sore masih berada di kawasan wisata Gronggong tersebut. Terdapat pula lapak pengunjung yang bersekat-sekat atau berbilik-bilik yang letaknya berada di bawah yang tidak terlihat jika dilihat dari arah jalan namun pemilik warungnya berada di atasnya. Tempat yang seperti itu tidak bisa dilihat oleh siapapun karena lokasinya berada di bawah, dan juga sangat gelap kalau malam hari hanya ada penerangan satu dan itu pun seadanya, kalau pada saat siang hari sangat sepi sekali itu dapat membuat pengunjung yang memilih tempat di situ bisa melakukan hal yang tidak diinginkan. Mereka memanfaatkan situasi dan kondisi seperti itu untuk melakukan perbuatan asusila dan kerap memanfaatkan lokasi tersebut untuk berbuat mesum.

2) Lapak pedagang dan lapak pengunjung berada di sebelah kanan jalan

Lapak pedagang yang berada pada sisi jalan sebelah kanan terbuka lebar tanpa sekat-sekat dan bilik-bilik namun bangkubangkunya berpencar sehingga ada jarak antar satu bangku dengan bangku yang lain dan juga dengan para pemilik lapak, sehingga banyak berdiri bangku-bangku yang berdiri tegak di atas bukit dan pada saat malam hari tanpa penerangan sama sekali. Jika pada malam hari terutama pada malam minggu lokasi inilah yang paling ramai dikunjungi oleh para pengunjung terutama para kawula muda yang berpasang-pasangan baik ada yang mengendarai sepeda motor dan membawa kendaraan beroda empat. Para pengunjung bebas memilih bangku mana yang mereka inginkan, kemudian terjadilah interaksi sosial antara para pedagang dan para pengunjung. Kebanyakan dari mereka pada saat peneliti melakukan penelitian di sana, pada malam hari banyak juga para pengunjung mayoritas para pasangan muda-mudi memilih bangku yang lokasinya jauh dari pemilik warung karena bangku yang berada pada sisi kanan jalan berpencar-pencar dan tanpa 
penerangan sama sekali sehingga jika kita lihat, di atas bukit itu tidak ada orang padahal jika kita dekati itu ada orangnya. Jadi tidak terlihat dari arah jauh karena sangat gelap. Pada saat peneliti melakukan penelitian, peneliti memergoki salah satu pengunjung yang sedang berciuman di lapak untuk pengunjung yang bertuliskan 'bangku di atas banyak'. Mereka menyadari kalau perbuatannya tersebut dilihat oleh orang lain, tetapi mereka tetap acuh seperti tidak pernah melakukan apa-apa. Selain itu, kalau kita mengetahui apakah di situ ada orang atau tidak, kita bisa mengetahuinya dari cahaya kendaraan bermotor dan bermobil mereka pada saat mereka ingin pulang. Mereka pada umumnya langsung memasukan kendaraannya baik mobil ataupun kendaraan bermotor hingga ke tempat gelap jauh dari jalan raya. Oleh karena itu banyak laporan dari pedagang asongan, para pengamen, para pengembala kambing atau pencari rumput, banyak terjadi istilahnya "mobil bergoyang" atau perbuatan mesum sambil duduk di atas bangku juga ditemukannya celana dalam dan kondom (Tertera dalam surat perjanjian pedagang yang ada di kawasan wisata Gronggong dengan aparat pemerintah setempat untuk membongkar bangunan dan mengosongkan bangunan yang bentuknya sekat-sekatan). Bukti lain yang di dapat, setahun yang lalu tepatnya Satpol PP pernah menemukan kondom pada saat melakukan pembongkaran di kawasan wisata Gronggong tersebut.

b. Kurangnya Lighting (Penerangan).

1) Lapak pedagang dan lapak pengunjung berada di sebelah kiri jalan

Lapak pengunjung yang berada kiri jalan memiliki penerangan lampu seadanya. Lapak pengunjung berupa gubuk-gubuk kecil bersekat-sekat yang berada di sebelah kiri jalan hanya diberi satu lampu untuk satu ruangan yang bisa ditempati tiga sampai empat orang pengunjung. Gubuk-gubuk kecil yang letaknya di bawah, tidak terlihat dari atas atau dari arah jalan, jika malam hari sangat gelap sekali penerangan hanya seadanya, sehingga kita tidak tahu apakah di sana ada orangnya ada atau tidak. Situasi dan kondisi yang seperti itu yang ditengarai untuk melakukan perbuatan yang melanggar nilai dan norma karena sangat gelap tidak terlihat oleh siapapun, sehingga pengunjung yang berada di sana merasa senang tidak diketahui orang lain.

2) Lapak pedagang dan lapak pengunjung berada di sebelah kanan jalan

Lapak pengunjung yang berada di sebelah kanan jalan, berupa bangku-bangku yang jaraknya berpencar-pencar memiliki penerangan lampu seadanya bahkan ada yang mendapat cahaya lampu dari para pemilik warungnya saja. Bangku-bangku yang dibangun berdiri tegak di atas bukit, jika kita lihat dari arah jauh pada saat malam hari, itu sangat tidak terlihat apakah 
ada orangnya atau tidak karena sangat gelap sekali tidak diberi penerangan. Walaupun lapak pengunjung sebelah kanan itu terbuka lebar, memiliki jarak bangku yang berpencar-pencar, tidak mendapatkan penerangan yang secukupnya ditengarai juga sering dimanfaatkan para pengunjungnya untuk berbuat halhal yang tidak diinginkan.

\section{c. Faktor Non Fisik}

1) Hubungan sosial yang dinamis antara pedagang dan pengunjung kawasan wisata Gronggong

Hubungan sosial antara pedagang dan pengunjung yang datang ketika berkunjung ke kawasan wisata Gronggong sangat dinamis. Sikap yang ditunjukkan para pedagang kepada para pengunjung sangat ramah, murah senyum, sehingga membuat para pengunjung senang. Para pedagang dengan senangnya mempersilahkan para pengunjung untuk memilih lapak pengunjung yang sesuai dengan keinginan pengunjungnya itu. Mereka bahkan ada yang menawarkan lapak pengunjungnya yang berada di dalam artinya berupa gubuk bersekat untuk para pengunjung yang datang, sehingga banyak pengunjung yang datang dan memilih tempat yang bersekat itu. Para pedagang pun tidak mengganggu kenyamanan para pengunjung yang datang ketika mereka sedang berada di lapak yang mereka pilih tadi, dan pengunjung pun merasa nyaman dan senang karena tidak ada batasan waktu yang mengikat untuk pengunjung datang ke kawasan wisata Gronggong tersebut, sehingga pengunjung dapat menghabiskan waktu sepuasnya datang ke kawasan wisata Gronggong tersebut. Selain itu, agar dagangannya laris dan ramai dikunjungi oleh pengunjung yang datang, para pedagang membangun lapak untuk para pengunjungnya yang menyalahi aturan karena menjadi penjual jagung di kawasan wisata Gronggong merupakan sumber penghasilan para warga masyarakat sekitar, sehingga para pedagang dengan idenya sendiri membangun konstruksi bangunan lapak yang menyalahi aturan Perda tentang K3 yaitu ketertiban, kebersihan, dan keindahan.

2) Faktor pengendalian sosial dari aparat pemerintah setempat kurang optimal.

Masih banyak ditemukan lapak para pengunjung yang menyalahi aturan Perda tentang K3 yaitu ketertiban, kebersihan, dan keindahan karena tidak semua lapak yang menyalahi aturan tersebut di bongkar oleh aparat pemerintah setempat. Pada saat peneliti melakukan penelitian di kawasan wisata Gronggong, masih melihat dan menemukan lapak yang menyalahi aturan tersebut. Pada saat aparat pemerintah setempat telah selesai melakukan penertiban, para pedagang di sana membangun kembali lapak-lapak untuk para pengunjungnya tersebut karena jika 
tidak dibangun kembali, maka pedagang tidak mendapatkan penghasilan dari berjualan jagungnya itu, sedangkan kawasan wisata Gronggong merupakan sumber mata pencaharian masyarakat sekitar. Oleh karena itu, sampai sekarang ini kawasan wisata Gronggong masih kerap dimanfaatkan untuk dijadikan tempat melakukan perbuatan mesum atau perbuatan asusila oleh pengunjung yang nakal karena salah satunya upaya pengendalian sosial dari aparat pemerintah setempat kurang optimal.

Sedangkan upaya aparat dan pemerintah setempat dalam mentertibkan kawasan wisata gronggong dari perilaku pergaulan bebas di kalangan remaja. Mendengar dan melihat laporan warga yang seperti itu dan juga untuk mentertibkan kawasan wisata Gronggong agar tidak terlihat kumuh, aparat pemerintah setempat seperti kantor kecamatan, kepala desa bekerjasama dengan Satuan Polisi Pamong Praja (Satpol PP) Kabupaten Cirebon, Kapolsek dan Koramil setempat melakukan upaya penertiban di kawasan wisata Gronggong sebagai berikut:

a. Pencatatan Lapak yang Bersekat-sekat

Pencatatan yang dilakukan oleh perangakat desa setempat kepada warung-warung yang memiliki sekat-sekat atau bilik-bilik yang kemudian dikonsultasikan dan koordinasi dengan pihak atas (Satpol PP, Muspika, Kapolsek setempat) tentang jadwal atau waktu diadakannya penertiban tanpa sepengetahuan para pedagang yang ada di sana.

b. Memberikan Pengarahan, Sosialisasi, dan Dalam Pengawasannya Melakukan Patroli.

Aparat pemerintah setempat kerap memberikan pengertian, pengarahan, dan bahkan sosialisasi kepada para pedagang yang ada di sana untuk tidak melanggar Perda kemudian dalam pengawasannya aparat pemerintah setempat juga melakukan patroli hampir setiap satu minggu sekali. Sosialisasi dilakukan dengan cara door to door melalui pendekatan persuasif mengobrol dan bertemu langsung dengan para pedagang di lokasi (di kawasan wisata Gronggong), apabila aparat pemerintah setempat sedang melakukan patroli, kemudian dengan cara mengumpulkan para pedagang di kantor kelurahan untuk diberikan pengarahan dan sosialisasi.

c. Melakukan Penertiban atau Razia

Jika para pedagang di sana membandel artinya masih ditemukannya lapak pedagang yang menyalahi aturan dan tidak melaksanakan dengan baik apa yang sudah diarahkan para aparat pemerintah setempat, dan untuk juga mentertibkan kawasan wisata Gronggong ini dari imej masyarakat bahwa kawasan wisata Gronggong tersebut dijadikan tempat untuk melakukan perbuatan yang melanggar nilai dan norma dalam masyarakat atau dimanfaatkan dan dijadikan tempat berbuat mesum oleh pengunjung yang nakal, maka Satuan Polisi Pamong Praja (Satpol 
PP) di bantu dengan Polres, Koramil dan pihak kecamatan setempat mentertibkan atau merazia lapaklapak para pedagang yang menyalahi aturan, dengan cara pembongkaran.

Penertiban yang dilakukan aparat setempat untuk mentertibkan kawasan wisata Gronggong dari imej yang seperti itu, dilakukan pada waktu-waktu tertentu dan tergantung dari kebutuhan, seperti menjelang hari-hari besar keagamaan, dan menjelang akhir tahun. Sistem patroli hampir setiap satu minggu sekali Satuan Polisi Pamong Praja (Satpol PP) melakukan patroli di kawasan wisata Gronggong tersebut tanpa memberitahukan kepada pedagang di sana kapan waktunya akan dilaksanakan sistem patroli dan akan diadakan razia atau penertiban. Setiap malam hari ada pula polisi malam yang berada di kawasan wisata Gronggong. Namun, penertiban yang dilakukan Satpol PP tersebut tidak mengena ke seluruh lapak-lapak yang ada di sana. Lapak-lapak pedagang yang berada di sisi kiri jalan yang konstruksi bangunan lapaknya bersekat-sekat atau berbilik-bilik tidak semuanya dibongkar. Hanya ada beberapa lapak saja. Lapaklapak yang berada diseberang ruas jalan sebelah kanan hampir semuanya dibongkar oleh satpol PP karena lapak-lapak yang berada di seberang ruas jalan sebelah kanan, kebanyakan bangku untuk para pengunjung letaknya berpencarpencar dan jauh dari pemilik warung bahkan sampai ada yang berada di atas bukit hal itu yang ditengarai dimanfaatkan untuk melakukan perbuatan yang melanggar nilai dan norma yang ada di masyarakat apalagi pada saat malam hari yang sangat gelap tanpa penerangan sama sekali.

Terdapat batasan antara pemilik warung dengan bangkubangku untuk para pengunjung jaraknya tidak boleh lebih dari 5 sampai 10 Meter. Jika masih ada pedagang yang membangun bangku-bangku yang jaraknya lebih dari 5 sampai 10 Meter itu pasti akan dibongkar oleh Satpol PP. Keinginan aparat pemerintah setempat dengan para pedagang terhadap lapak-lapak pengunjung yang ada di kawasan wisata Gronggong itu berbeda. Keinginan aparat pemerintah setempat, menginginkan lapak-lapak pengunjung yang terbuka, bisa dilihat dari berbagai sisi, dan tidak melanggar Perda, namun keinginan para pedagang, mereka membangun lapak-lapak yang bersekat-sekat tersebut jika hujan, para pengunjungnya tidak kehujanan, dan jika panas pengunjungnya tidak kepanasan.

Pembongkaran lapak-lapak yang menyalahi aturan tersebut yang dilakukan oleh aparat pemerintah setempat diwarnai aksi protes dan perlawanan oleh para pedagang. Mereka melakukan perlawanan itu biasa, tetapi setelah aparat pemerintah setempat telah selesai mentertibkan kawasan wisata Gronggong tersebut, mereka 
akan membangun kembali bangkubangku yang telah dibongkar tadi. Jika bangku-bangku mereka tidak dibangun kembali, maka para pedagang tersebut tidak bisa mendapatkan uang untuk memenuhi kebutuhan hidupnya. Dampak dari adanya lapak-lapak yang ada di kawasan wisata Gronggong tersebut memberikan dampak yang sangat besar bagi bagi perekonomian masyarakat sekitar. Menjadi penjual jagung di kawasan wisata Gronggong merupakan mata pencaharian warga desa atau masyarakat setempat yang mayoritas penjual jagung yang ada di kawasan wisata Gronggong mayoritas penduduk sekitar atau warga masyarakat Desa Patapan itu sendiri namun ada juga yang dari luar Desa Patapan hanya ada beberapa saja.

Jika kita lihat dan amati, konstruksi bangunan lapak mereka sudah jelas merusak keindahan, bangunannya pun dibangun asal saja dan melanggar perda tentang K3 yaitu kebersihan, ketertiban, dan keindahan. Aparat pemerintah setempat hanya membantu para pedagang untuk memindahkan dari tempat yang terkena penertiban ke tempat yang mereka inginkan atau di kembalikan kerumahnya kalau mereka memang yang melanggar. Pemindahan tersebut terserah para pedagang, apakah mereka ingin pindah kerumahnya sendiri atau ke tempat yang sudah ditentukan yaitu yang di sebelah ruas kanan jalan. Namun tidak ada ganti rugi baik materi atau apapun. Aparat pemerintah setempat tidak berharap kawasan wisata Gronggong yang seharusnya menjadi bagian dari pada wisata kuliner karena di sana tersaji berbagai macam banyak makanan, ada imej bahwa di sana tempat untuk melakukan perbuatan-perbuatan yang dilarang. Selama penertiban itu dilakukan tidak ada konflik artinya, tidak ada perlawanan fisik dari para pedagang dengan aparat pemerintah setempat. Muncul reaksi atau perlawanan dari para pedagang itu biasa namun tidak sampai pada perlawanan fisik. Para pedagang hanya pasrah saja karena posisi mereka sangat lemah, bahkan ada yang berteriak-teriak memohon kepada aparat pemerintah setempat agar lapak dagangannya jangan dibongkar karena untuk membangun bangku-bangku saja mereka harus menyisihkan keuntungan dari berjualan jagung. Namun tetap saja jika para aparat pemerintah setempat telah selesai melakukan penertiban, para pedagang membangun kembali bangku-bangku tersebut.

\section{Daftar Pustaka}

Burhan Bungin. (2003). Metodologi Penelitian Kualitatif Aktualisasi Metodologis Ke Arah Ragam Varian Kontemporer. Jakarta : PT Raja Grafindo Persada.

Craib Ian. (1992). Teori-Teori Sosial Modern Dari Parsons sampai Habermas. Jakarta : CV Rajawali.

Ida Bagoes Mantra. (2008). Filsafat Penelitian dan Metode Penelitian Sosial. Yogyakarta : Pustaka Pelajar. 
Fenomena Lapak Mesum

Irawan Soehartono. (2002). Metode Penelitian Sosial Suatu Teknik Penelitian Bidang Kesejahteraan Sosial dan Ilmu Sosial Lainnya. Bandung : Remaja Rosda.

J. Dwi Narwoko. (2010). Sosiologi Teks Pengantar dan Terapan, Jakarta : Kencana.

Kartini Kartono. (2007). Patalogi Sosial. Jakarta : PT Raja Grafindo Persada.

Kamus Besar Besar Bahasa Indonesia Edisi Ketiga. (2005). Jakarta : Departemen Pendidikan Nasional Balai Pustaka.

Lexy J. Moleong. (2006). Metodelogi Penelitian Kualitatif. Bandung: Remaja Rosdakarya.

Magaret M. Poloma. (2007). Sosiologi Kontemporer. Jakarta : Raja Grafindo Persada.

Miles Dan Huberman. (1992). Analisa Data Kualitatif. Jakarta : UI Press.

Nasution. (2003). Metode Penelitian Naturalistik Kualitatif. Bandung : Tarsito.

Ritzer, George. (2004). Teori Sosiologi Dari Sosiologi Klasik Sampai Perkembangan Mutakhir Teori Sosial Postmodern. Yogyakarta : Kreasi Wacana.
Sanapiah Faisal. (2005). Formatformat Penelitian Sosial. Jakarta : Raja Grafindo Persada.

Sarlito Wirawan Sarwono. (2006). Psikologi Remaja. Jakarta: PT. Grafindo Persada.

Soerjono Soekanto. (2005). Sosiologi Suatu Pengantar. Jakarta : PT. Grafindo Persada.

Soetomo. (2008). Masalah Sosial Dan Upaya Pencegahannya, Yogyakarta : Pustaka Pelajar,

Sofyan S. Willis. (2005). Remaja Dan Masalahnya Mengupas Berbagai Bentuk Kenakalan Remaja Seperti Narkoba, Free Sex Dan Pemecahannya. Bandung : Alfabeta.

\section{Skripsi:}

Nur Ika Septiyani. (2009). Skripsi: Persepsi Masyarakat Terhadap Perilaku Pacaran Remaja di Dusun Dalangan Desa Triharjo Kecamatan Wates Kabupaten Kulon Progo. Yogyakarta: UNY.

Tutik Antini. (2009). Skripsi: Persepsi Masyarakat Dusun Nogosari I, Wukirsari Imogiri Bantul Terhadap Fenomena Seks Bebas di Kalangan Remaja. Yogyakarta: UNY.

Tatang M. Amirin, dalam Vina Emiyati. (2006). Skripsi: Pengaruh Tingkat Profesionalitas Guru Terhadap Kreativitas Prasekolah di TK Aisyiyah Bustanul Athfal "ABA" Sapen. Yogyakarta. Yogyakarta: UII. 


\section{Internet:}

Indah Septiyaning, 2010, Lapak mesum di wisata Gronggong dikukut. Tersedia pada

http://www.solopos.com/2010/ch annel/nasional/lapak-mesum-diwisata-gronggong-dikukut. Diakses pada tanggal 17 Maret 2010.

--_apak Mesum Kawasan Wisata Gronggong dibongkar. Tersedia pada http://www.antarajawabarat.com/1 ihat/berita/20733/Lapak-MesumKawasan-Wisata-Gronggongdibongkar. Diakses pada tanggal 17 Maret 2010.

\section{Dokumen lainnya :}

Arsip surat perjanjian pedagang dengan aparat pemerintah setempat untuk sedia mengkosongkan warung yang berbilik-bilik (di kantor Dinas Kebudayaan, Pariwisata Pemuda dan Olahraga (Disbudparpora) kabupaten Cirebon).

Arsip data monografi Desa Patapan Kecamatan Beber Kabupaten Cirebon

Leflet Potensi Pariwisata Kabupaten Cirebon Oleh Disbudparpora kabupaten Cirebon 2009. 